\author{
Marquette University \\ e-Publications@Marquette
}

College of Education Faculty Research and

Publications

Education, College of

8-2005

\title{
Perceptions of Multicultural Training in Predoctoral Internship Programs: A Survey of Interns and Training Directors
}

\author{
Jeana L. Magyar-Moe \\ University of Wisconsin - Stevens Point \\ Jennifer Teramoto Pedrotti \\ California Polytechnic State University - San Luis Obispo \\ Lisa Edwards \\ Marquette University, lisa.edwards@marquette.edu \\ Alicia Ito Ford \\ University of Kansas Main Campus \\ Heather N. Rasmussen \\ University of Pittsburgh - Main Campus
}

See next page for additional authors

Follow this and additional works at: https://epublications.marquette.edu/edu_fac

Part of the Education Commons

\section{Recommended Citation}

Magyar-Moe, Jeana L.; Pedrotti, Jennifer Teramoto; Edwards, Lisa; Ford, Alicia Ito; Rasmussen, Heather N.; and Ryder, Jamie A., "Perceptions of Multicultural Training in Predoctoral Internship Programs: A Survey of Interns and Training Directors" (2005). College of Education Faculty Research and Publications. 49.

https://epublications.marquette.edu/edu_fac/49 
Authors

Jeana L. Magyar-Moe, Jennifer Teramoto Pedrotti, Lisa Edwards, Alicia Ito Ford, Heather N. Rasmussen, and Jamie A. Ryder

This article is available at e-Publications@Marquette: https://epublications.marquette.edu/edu_fac/49 


\title{
Perceptions of Multicultural Training in Predoctoral Internship Programs: A Survey of Interns and Training Directors
}

\author{
Jeana L. Magyar-Moe \\ Psychology Department, University of Wisconsin-Stevens Point \\ Stevens Point, WI \\ Jennifer Teramoto Pedrotti \\ California Polytechnic State University, San Luis Obispo \\ San Luis Obispo, CA \\ Lisa M. Edwards \\ Department of Psychology, University of Notre Dame \\ Notre Dame, IN \\ Alicia Ito Ford \\ Counseling Psychology, University of Kansas \\ Lawrence, $K S$ \\ Stephanie E. Petersen \\ Counseling Psychology, University of Kansas \\ Lawrence, $K S$ \\ Heather N. Rasmussen \\ University of Pittsburgh and Carnegie Mellon University \\ Jamie A. Ryder \\ Counseling Psychology, University of Kansas \\ Lawrence, $K S$
}

Professional Psychology: Research and Practice, Vol. 36, No. 4 (August 2005): pg. 446-450. DOI. This article is (C) American Psychological Association and permission has been granted for this version to appear in e-Publications@Marquette. American Psychological Association does not grant permission for this article to be further copied/distributed or hosted elsewhere without the express permission from American Psychological Association. 
NOT THE PUBLISHED VERSION; this is the author's final, peer-reviewed manuscript. The published version may be accessed by following the link in the citation at the bottom of the page.

Multicultural training at internship sites is a critical component in the preparation of doctoral-level psychologists, so the quality of this training is of the utmost importance. In the following study, the authors examine multicultural training from the perspective of predoctoral interns and training directors at counseling center sites that offer a major or minor rotation in multicultural therapy. Results suggest that perspectives vary between interns and training directors and that there is a great difference in the type of criteria used by each site as evidence of a major or minor rotation. The need for more standardized criteria to define major and minor rotations and suggestions for the Association of Psychology Postdoctoral and Internship Centers, internship training directors, and prospective interns are discussed.

How do interns and training directors perceive the quality of multicultural training at their internship sites? In general, previous studies clearly indicate the need for increased attention to multicultural issues in all internship programs (Constantine \& Gloria, 1999). Beginning with the 2001-2002 edition of the Association of Psychology Postdoctoral and Internship Centers' (APPIC, 2001) directory, sites have been invited to indicate their level of multicultural training by listing a major or minor rotation in multicultural therapy. There are no defined criteria, however, for how training directors can or should designate these rotations. Furthermore, there is a dearth of research about interns' perspectives of multicultural training and service delivery. The current study is designed to examine the amount and type of multicultural training received by interns, as reported by the training directors and interns themselves, at American Psychological Association (APA)-accredited university counseling centers listed in the APPIC directory as having major or minor training rotations in multicultural therapy.

\section{Survey of Multicultural Training}

Participants were training directors and interns from APAaccredited predoctoral internship sites at university counseling centers offering a major or minor rotation in multicultural therapy, as listed in the 2001-2002 APPIC directory. Sixty-six training directors (36 from sites listing major rotations in multicultural therapy and 30 from sites listing minor rotations in multicultural therapy) were mailed research packets. In addition, the training directors were asked to disseminate similar research packets to each of their current predoctoral interns for completion (132 interns from sites listing major rotations in 
multicultural therapy and 107 interns from sites listing minor rotations in multicultural therapy).

Intern and training director participants were asked to provide general descriptive data about their internship sites and to rate 25 statements on a 4 -point Likert scale $(1=$ not at all true to $4=$ definitely true) that assessed the extent to which certain multicultural issues were addressed in their programs. Items were adapted from the Multicultural Competency Checklist (Ponterotto, Alexander, \& Grieger, 1995) by Constantine and Gloria (1999) and adopted for use in this study with written permission of the authors. In addition, both interns and training directors were asked to report how they felt their internship site was doing with regard to multicultural training of interns on a 5-point Likert scale ( $1=$ not at all adequate to $5=$ very well). Finally, several different open-ended response items were included on training director and intern questionnaires.

A total of 16 training directors and 42 interns returned surveys, a $24 \%$ response rate for training directors and an $18 \%$ response rate for interns. The demographic characteristics of participants in this study, as presented in Table 1, are representative of those found among doctoral-level psychologists according to a 2002 survey conducted by the National Opinion Research Center at the University of Chicago (Bailey, 2004). Likewise, participant demographics also correspond to information collected by the APA Research Office (Pate, 2001) for students seeking internship in 2000.

Eleven of the 16 (69\%) returned training director surveys and 23 of the $42(55 \%)$ returned intern surveys came from participants at internship sites listed as providing major rotations in multicultural therapy, and the remaining 5 (31\%) training director surveys and 19 $(45 \%)$ intern surveys were from sites listed as providing minor rotations in multicultural therapy. Because of the low rate of return, formal statistical analyses could not be conducted as originally anticipated; thus, general trends were observed and reported. Most important, two main issues were discovered in the self-report responses of the training directors and the interns: (a) discrepancies in self-reported hours between training directors and interns in major and minor rotations and (b) inconsistencies in criteria being used to define a site as having a major multicultural rotation versus a minor

Professional Psychology: Research and Practice, Vol. 36, No. 4 (August 2005): pg. 446-450. DOI. This article is (C) American Psychological Association and permission has been granted for this version to appear in e-Publications@Marquette. American Psychological Association does not grant permission for this article to be further copied/distributed or hosted elsewhere without the express permission from American Psychological Association. 
rotation in this area. These initial findings serve to support our hypothesis that greater attention needs to be given to the standardization of criteria used to describe multicultural training available at internship sites.

\section{Discrepancies in Self-Reported Hours Between Training Directors and Interns}

With regard to the estimated number of hours spent on multicultural training, discrepancies existed among and between training directors and interns at both major and minor rotation sites. More specifically, the average number of hours spent on multicultural training issues was reported by interns and training directors to be slightly higher at sites listed as providing minor rotations in comparison to the average number of hours reported at sites listed as having major rotations. In addition, regardless of multicultural therapy rotation designation, interns reported fewer hours devoted to training in the area of multicultural therapeutic issues when compared with training directors' reports. These findings suggest that the criteria for classifying internship training experiences need to be standardized so that accurate information about the appropriate multicultural designation is presented and understood by all involved in the training endeavor.

\section{Criteria Used for Designation of Site as Major or Minor}

An informal examination of these data revealed that training directors used two general criteria to determine whether their internship sites provided major versus minor multicultural therapy rotations: (a) the number of diverse clients that interns were able to work with throughout the training year and (b) the training opportunities in multicultural issues that were available to interns. These categories appeal to common sense; however, the lack of standardized criteria (i.e., on average, how many diverse clients and how many hours of multicultural training could an intern expect to receive at a site listed as providing a major vs. minor rotation in multicultural therapy) is problematic. Additionally, discrepancies were found in the self-report responses of five training directors about the status of their sites as providers of major versus minor rotations in

Professional Psychology: Research and Practice, Vol. 36, No. 4 (August 2005): pg. 446-450. DOI. This article is (C) American Psychological Association and permission has been granted for this version to appear in e-Publications@Marquette. American Psychological Association does not grant permission for this article to be further copied/distributed or hosted elsewhere without the express permission from American Psychological Association. 
multicultural therapy when their responses were compared with their site's listing in the APPIC directory. More specifically, one training director indicated that the internship site had both a major and a minor rotation in multicultural therapy, although the site was listed in the APPIC directory as having only a minor multicultural therapy rotation. Another training director identified the site as providing a minor rotation in multicultural therapy, whereas the center was listed in the directory as offering a major multicultural therapy rotation. Three training directors reported that their sites offered major rotations in multicultural therapy, although their sites were listed as offering minor rotations in the directory. Hence, it appears that the meaningfulness of the APPIC directory listings and the attention given to this aspect of training by training directors could be greatly improved by operationalizing the differences between major and minor rotation categories.

\section{Summary and Implications for Interns and Training Sites}

The results from this study suggest that the two most salient issues are inconsistencies in the amount of time devoted to multicultural training and the lack of criteria used to designate a major or minor rotation in multicultural therapy. Although the current study is limited because of the low overall response rates of interns (18\%) and training directors (24\%) and because the opinions voiced are largely those of White training directors (94\%) and White interns $(86 \%)$, the information from this study may serve as a springboard for discussing the complex issue of evaluating multicultural content and training in internship programs. Specifically, numerous preliminary recommendations based on this pilot survey study have been developed for APPIC, training directors, and prospective interns.

\section{Recommendations for APPIC}

The most beneficial changes to this aspect of internship training would result from the creation of standardized criteria for the delineation of major versus minor rotations. Such criteria should be formulated by a specially appointed APPIC subcommittee. Suggested criteria include requiring a set number of training hours devoted to 
multiculturalism and diversity issues; having a member of the training staff designated as a mentor for interns needing assistance in this area; requiring a set number of specific programs, committees, and outreach activities related to multiculturalism; and specifying sites with higher percentages of minority clients. This would provide more information for interns seeking out specialized training in the area of multiculturalism. In addition, set criteria might encourage internship site directors to strive toward giving their sites a multicultural distinction, thereby encouraging the centers' training staff to make this area a priority in their training.

\section{Recommendations for Training Directors}

Until such standardized criteria are created by APPIC, there are several ways that training directors can help students navigate the internship application process and make more informed decisions regarding multicultural training at their internship sites. Training directors should compile as much detailed information as possible about the multicultural training and service delivery available at their internship sites and include these findings in their internship brochures, application materials, and/or Web sites. Pertinent details to address include basic information, such as the number of seminar hours devoted to multicultural and diversity issues, as well as more specific information regarding other ways multicultural training is achieved in the training program, such as the proportion of multicultural clientele and supplementary training experiences that are available. Prospective interns could also benefit from knowing the multicultural training and experiences of staff members, especially those conducting diversity seminars, and the evaluation criteria and assessment strategies used to measure intern multicultural competence on completion of the training program. By making such information available, training directors would help to facilitate a closer match between the training opportunities available at their sites and the expectations of internship applicants.

\section{Recommendations for Prospective Interns}

Prospective interns seeking information about multicultural training at internship sites might benefit from considering the 
information provided in the Appendix. This checklist can serve as a potential aid to graduate students who are navigating the process of internship site selection. In this way, they may identify which sites have the types of multicultural experiences they desire. Students may use the checklist as they begin to investigate their options and/or as a resource to guide more in-depth questions during interviews.

In addition, given the differences between training director and intern survey responses in this study, students embarking on the internship selection process are strongly advised to contact not only training directors but also current interns at sites of interest to discuss their opinions of the multicultural training received during internship. Finally, because of the current lack of standardization across sites regarding their emphases in multicultural training, prospective interns are encouraged to refrain from completely ruling in or out those sites that may be of interest solely on the basis of their designation regarding multicultural therapy in the APPIC directory.

\section{Future Directions}

Because only university counseling center staff and interns were solicited for participation in this study, future studies should be aimed at surveying interns and training directors from non-counseling center internship sites as well. Because of the low sample size, statistical comparisons of intern versus training director responses at sites with major versus minor multicultural therapy rotations could not be conducted; however, future studies should be aimed at running such comparisons. If significant discrepancies between intern and training director perspectives are revealed, changes in the training program may need to be considered and implemented. Finally, because the items from the adopted survey used in this study were related to multiculturalism regarding racial and ethnic issues only, other aspects of culture, including sexuality, religion, disability status, age, and gender issues, were not examined. Future studies examining these other components of culture are in order.

As the field of psychology as a whole begins to take a more comprehensive look at culture in clients and in the world in general, good training in multicultural issues becomes a necessity. Internship sites have done much over the years to incorporate a more culturally

Professional Psychology: Research and Practice, Vol. 36, No. 4 (August 2005): pg. 446-450. DOI. This article is (C) American Psychological Association and permission has been granted for this version to appear in e-Publications@Marquette. American Psychological Association does not grant permission for this article to be further copied/distributed or hosted elsewhere without the express permission from American Psychological Association. 
NOT THE PUBLISHED VERSION; this is the author's final, peer-reviewed manuscript. The published version may be accessed by following the link in the citation at the bottom of the page.

balanced approach to their training. Future studies designed to look more closely at these efforts are both relevant and appropriate.

\section{References}

Association of Psychology Postdoctoral and Internship Centers. (2001). 20012002 Association of Psychology Postdoctoral and Internship Centers directory. Washington, DC: Author.

Bailey, D. S. (2004, February). Number of psychology PhDs declining. Monitor on Psychology, 35, 18-19.

Constantine, M. G., \& Gloria, A. M. (1999). Multicultural issues in predoctoral programs: A national survey. Journal of Multicultural Counseling and Development, 27, 42-53.

Pate, W., II. (2001). 2000 Demand for predoctoral internship survey. Retrieved April 2004 from the American Psychological Association Research Office Web site: http://0research.apa.org.libus.csd.mu.edu/00predocreport.html

Ponterotto, J. G., Alexander, C. M., \& Grieger, I. (1995). A multicultural competency checklist for counseling training programs. Journal of Multicultural Counseling and Development, 23, 11-20.

Professional Psychology: Research and Practice, Vol. 36, No. 4 (August 2005): pg. 446-450. DOI. This article is (C) American Psychological Association and permission has been granted for this version to appear in e-Publications@Marquette. American Psychological Association does not grant permission for this article to be further copied/distributed or hosted elsewhere without the express permission from American Psychological Association. 
NOT THE PUBLISHED VERSION; this is the author's final, peer-reviewed manuscript. The published version may be accessed by following the link in the citation at the bottom of the page.

\section{Appendix}

Appendix

Multicultural Internship Information Checklist for Prospective Interns

\begin{tabular}{|c|c|}
\hline POINTS TO CONSIDER IN INTERNSHIP SELECTION & $\begin{array}{l}\text { Name of internship site = } \\
\text { Source(s) of information: } \\
\text { APPIC Directory only: yes } \\
\text { Training director/other senior staff: yes } \\
\text { Name of contact = } \\
\text { Current intern(s): yes } \overline{\text { Name of current intern(s) }=}\end{array}$ \\
\hline $\begin{array}{l}\text { Site has a MAJOR multicultural rotation? } \\
\text { yes __ no } \\
\text { Discrepancy between APPIC listing information and information from training director/staff? } \\
\text { yes__ no }\end{array}$ & Notes: \\
\hline $\begin{array}{l}\text { Site has a MINOR multicultural rotation? } \\
\text { yes no no } \\
\begin{array}{l}\text { Discrepancy between APPIC listing information and information from training director/staff? } \\
\text { yes __ no }\end{array}\end{array}$ & Notes: \\
\hline $\begin{array}{l}\text { Site's definition of "multicultural rotation?" } \\
\text { Definition provided? ___ yes ___ no }\end{array}$ & Notes: \\
\hline $\begin{array}{l}\text { Diverse clientele seen at this site? } \\
\text { Percentages of types of clients seen? } \\
\text { Information available? } \\
\text { yes no no }\end{array}$ & Notes: \\
\hline $\begin{array}{l}\text { Assessment strategies and evaluation criteria used to measure intern multicultural } \\
\text { competence upon completion of the training program? } \\
\text { Information available? } \\
\text { yes__ no }\end{array}$ & Notes: \\
\hline $\begin{array}{l}\text { Seminars or specific training in multicultural topics available? ___ yes ___ no } \\
\text { Number of hours devoted to such training? } \\
\text { Pertinent multicultural training/background of seminar leaders? }\end{array}$ & Notes: \\
\hline $\begin{array}{l}\text { Types of diversity represented at site: } \\
\text { Race/ethnicity yes yes no no } \\
\text { Religion } \\
\text { Sexual orientation_ yes_ no } \\
\text { Disability yes_ no no } \\
\text { Other_ yes no no }\end{array}$ & Notes: \\
\hline
\end{tabular}

Note. $\quad$ APPIC $=$ Association of Psychology Postdoctoral and Intemship Centers.

Professional Psychology: Research and Practice, Vol. 36, No. 4 (August 2005): pg. 446-450. DOI. This article is (C) American Psychological Association and permission has been granted for this version to appear in e-Publications@Marquette. American Psychological Association does not grant permission for this article to be further copied/distributed or hosted elsewhere without the express permission from American Psychological Association. 
NOT THE PUBLISHED VERSION; this is the author's final, peer-reviewed manuscript. The published version may be accessed by following the link in the citation at the bottom of the page.

\section{Appendix}

Multicultural Internship Information Checklist for Prospective Interns

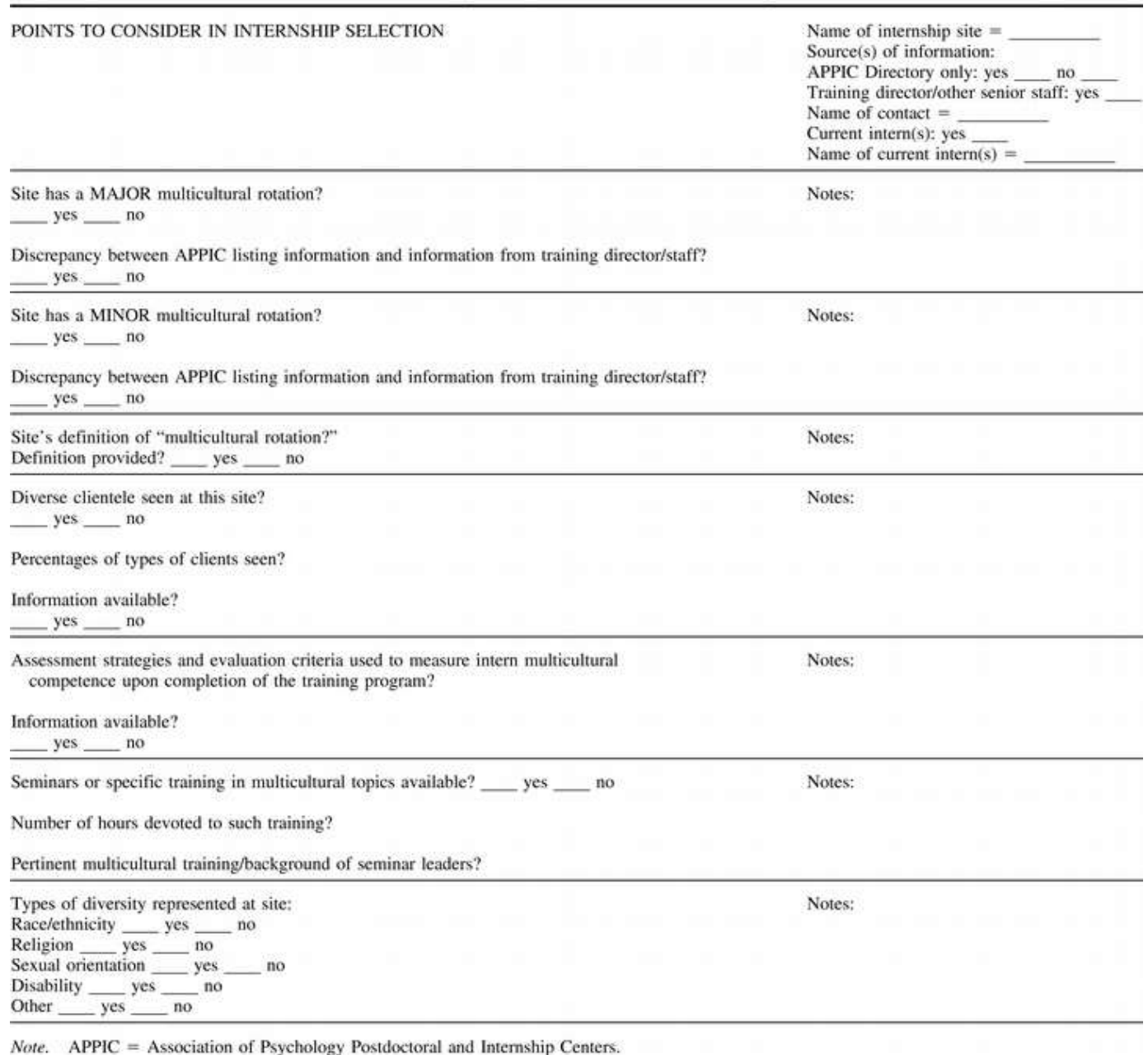

Note. $\quad$ APPIC $=$ Association of Psychology Postdoctoral and Internship Centers.

Professional Psychology: Research and Practice, Vol. 36, No. 4 (August 2005): pg. 446-450. DOI. This article is (C) American Psychological Association and permission has been granted for this version to appear in e-Publications@Marquette. American Psychological Association does not grant permission for this article to be further copied/distributed or hosted elsewhere without the express permission from American Psychological Association. 